If you do not need this report after it has served your purpose, please return it to the Geological Survey, using the official mailing label at the end

UNITED STATES DEPARTMENT OF THE INTERIOR

Harold L. Ickes, Secretary

GEOLOGICAL SURVEY

W. C. Mendenhall, Director

Bulletin 886-B

\title{
GEOLOGIC FACTORS IN THE INTERPRETATION OF FLUORSPAR RESERVES IN THE ILLINOIS-KENTUCKY FIELD
}

BY

\author{
L. W. CURRIER
}

Prepared in cooperation with the ILLINOIS STATE GEOLOGICAL SURVEY

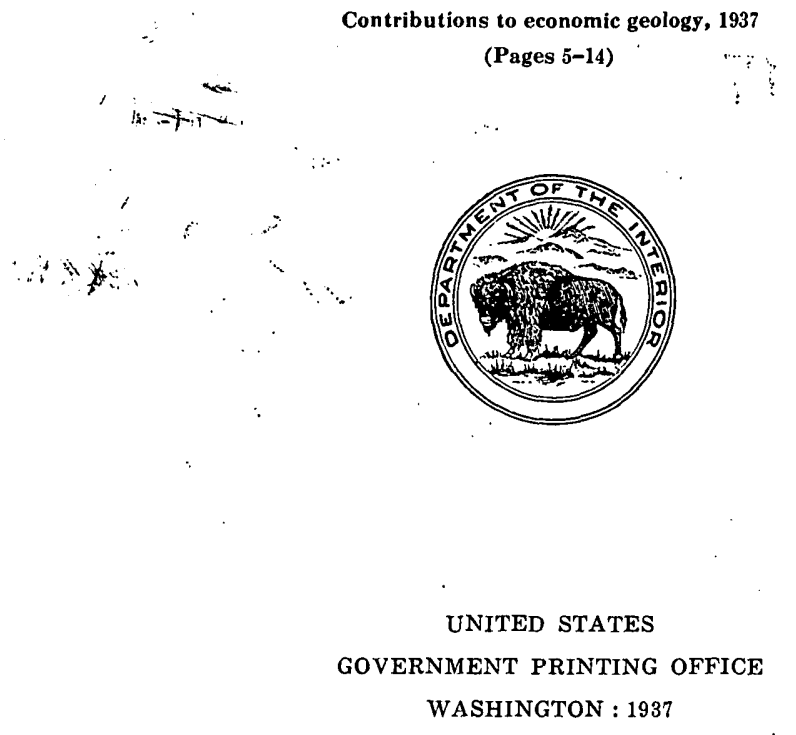

For sale by the Superintendent of Documents, Washington, D. C. - - - - - - Price 5 cents 


\section{CONTENTS}

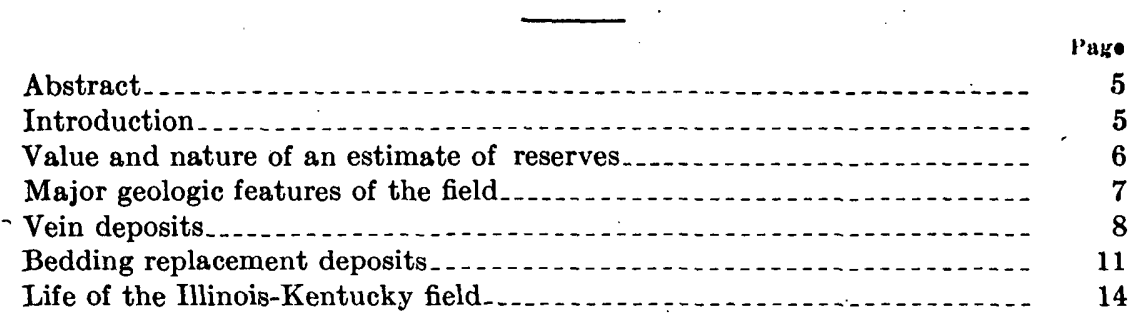

\section{ILLUSTRATIONS}

Plate 1. Production, importation, and utilization of fluorspar and production of open-hearth steel, 1916-35 . . . . . . . . . . . .

Figdre 2. Map of Illinois-Kentucky fluorspar fiẹld.

Page

II 


\title{
GEOLOGIC FACTORS IN THE INTERPRETATION OF FLUORSPAR RESERVES IN THE ILLINOIS-KENTUCKY FIELD
}

\author{
By L. W. CURrier
}

\section{ABSTRACT}

The importance of fluorspar to the steel industry and the apparently small reserves in the Illinois-Kentucky field (which produces over 90 percent of the domestic fluorspar) make it desirable to evaluate the geologic factors upon which an earlier estimate of reserves has been made. The structural relations and origin of the deposits suggest an uneven distribution of deposits over the area and greater depths of mineralization on some veins than on others. The Cave in Rock district of the Illinois portion of the field presents a unique geological relationship between the deposits, stratigraphic position, and minor structural features, and the potential resonrces of this district must be judged on a markedly different basis; a new estimate of reserves for this district places its future production at 500,000 tons or more. This figure should, however, be most useful as a stimulation for prospecting rather than as an even moderately close estimate of resources, because assumptions must be made regarding the percentage of the area that is mineralized; in other words, an uncertain areal factor is substituted for the uncertain depth factor of the veins.

The average yearly consumption of fluorspar in the United States for some years to come is estimated at 175,000 tons. This figure has been arrived at by considering statistics of production and utilization of both the fluorspar and steel industries. At this rate the estimated fluorspar reserves of the entire field will last from 30 to 35 years. This estimate will be affected by fluctuating imports, new utilization of fluorspar, and beneficiation of low-grade deposits, but no evaluation of these factors can be made. It is safe to say, however, that the Jllinois-Kentucky field still has a considerable reserve of fluorspar and will continue to dominate domestic production for several years and that there is no immediate cause for alarm concerning our resources of fluorspar.

\section{INTRODUCTION}

Fluorspar cannot be considered a deficiency mineral in the United States at present. Domestic producers will probably be able to satisfy requirements for several decades, although proved reserves are comparatively very small. The expectations are based upon rather comprehensive knowledge of the geologic factors governing the localization of the mineral in the Illinois-Kentucky field, from which over 90 percent of the domestic production is marketed. Nor should fluorspar be considered a strategic mineral in the generally accepted sense of this term. Nevertheless, it is of great 
importance in that it materially facilitates the production of openhearth steel, and consequently it definitely enters the war-minerals picture. For this reason a revised estimate of fluorspar reserves and an opinion regarding the life of the field in the light of recent. geologic investigations are worth while.

For the most part the Illinois-Kentucky fluorspar field does not lend itself even to a moderately close estimate of reserves. Except. in a very few mines there has been a lack of planned systematic: and thorough explorations in advance of development. An areal view of the field appears to show that much of it has been superficially attacked for quick returns on small investments. This mode. of procedure has necessarily been brought about by the limited use of the product and the rapid and great fluctuations in the market. A glance at production and consumption curves (pl. 1) will suffice to demonstrate this fact. It is axiomatic that the fluorspar-mining industry has been a shadow of the basic open-hearth steel industry and has been subject therefore to the vicissitudes of that industry, as from 70 to 80 percent of the fluorspar produced goes to the steel plants. Fluctuating imports have clearly played an important part in the economic drama and have markedly, affected the demands for domestic fluorspar, especially in periods of business depressionthe very times when domestic producers are in greatest need of an assured market. It is not strange, therefore, that very few fluorspar mines have been in continuous production or development.

\section{VALUE AND NATURE OF AN ESTIMATE OF RESERVES}

Judgment of reserves is a logical function of a public organization concerned with the geology of mineral resources. It provides an index of national independence as regards future supplies of the commodity considered and should be the key to policies of national conservation. It provides a basis for determining the relative positions of producing districts in the broad economic set-up of the industry. Knowledge of reserves, even though it may. be scant, aids in orienting the mining industry with respect to future investment. It is a factor also in the solution of international as. well as national economic problems.

Unfortunately, by its very nature, a statement of probable reserves. is not susceptible of being accurately expressed, for it is largely a. prophecy based upon intangible or incomplete evidence. The quantity of mineral available in a property, as Henry Louis has said, "is never known and never can be known until the whole of the mineral has been worked out from the property in question, when the information is naturally worthless." Nevertheless, it is important to form some rational opinion of reserves, with full recognition, of course, of the degree of uncertainty of the factors involved. In considering estimates of mineral reserves it must be fully realized 
that they represent only the nearest approach that can be made from the indefinite and variable data at hand. At best, the estimates can only approximate the mean between two probable and widely separated limits. If these facts are held clearly in mind,.it is justifiable to consider the matter of possible reserves even where mining development falls far short of indicating the extent and limits of mineralized ground in a district. Although a reasonably satisfactory calculation of possible reserves can be made only through development and exploration, nevertheless geologic interpretation of an area and its deposits may become of exceptional importance in the formulation of an opinion regarding the potentialities of a district. Through the study of developed mineral deposits, their structural, lithologic, and genetic features may often be determined and be used in the interpretation of the region as a whole, as well as in the search for specific areas worthy of exploration. As geologic conditions form so important a basis for the estimation of reserves, the pertinent geologic features of the Illinois-Kentucky fluorspar field and their bearing on the problem of reserves are reviewed below, and finally the expected life of the field is considered.

\section{MAJOR GEOLOGIC FEATURES OF THE FIELD ${ }^{2}$}

The fluorspar deposits of the Illinois-Kentucky field are of two types-vertical or nearly vertical veins in fault fissures and horizontal tabular and lenticular replacement bodies in limestone. The vein deposits constitute by far the bulk of the resources and are widely distributed throughout the field. The exploited horizontal replacement deposits are confined to a small area in Illinois on the margin of the field, known as the Cave in Rock district. (See fig. 2.)

The Illinois-Kentucky field displays a large structural dome of stratified rocks that has collapsed through faulting into a mosaic of elongated slabs and wedges. (See fig. 2.) The major surface dimensions of the dome are about 30 miles from northwest to southeast and 20 miles from northeast to southwest. The dome was invaded at depth by molten materials, some of which ascended along cracks and congealed as the peridotite dikes that are exposed at many places throughout the field. The chemical and mineralogic characteristics of these igneous bodies indicate that the constituents of the deep-seated magma from which they came had separated into materials of greatly contrasting chemical constitution before the intrusion and that one of the separate portions was exceptionally rich in volatile components. The known common association of the element fluorine with igneous rocks, the common occurrence of fluorspar in

\footnotetext{
1 Weller, Stuart, and collaborators, Geology of Hardin County : Illinois Geol. Survey Bull. 41, 1920. Currier, L. W., Fluorspar deposits of Kentucky : Kentucky Geol. Survey, ser. 6, vol. 13, 1923. Bastin, E. S., The fluorspar deposits of Hardin and Pope Counties, Ill. : Illinios Geol. Survey Bull. 58, 1931.
} 
veins of igneous affiliations, the structural and mineralogic features of the Illinois-Kentucky veins, and the coincidental geographic concentration of the fluorspar veins and the igneous rocks lead to the

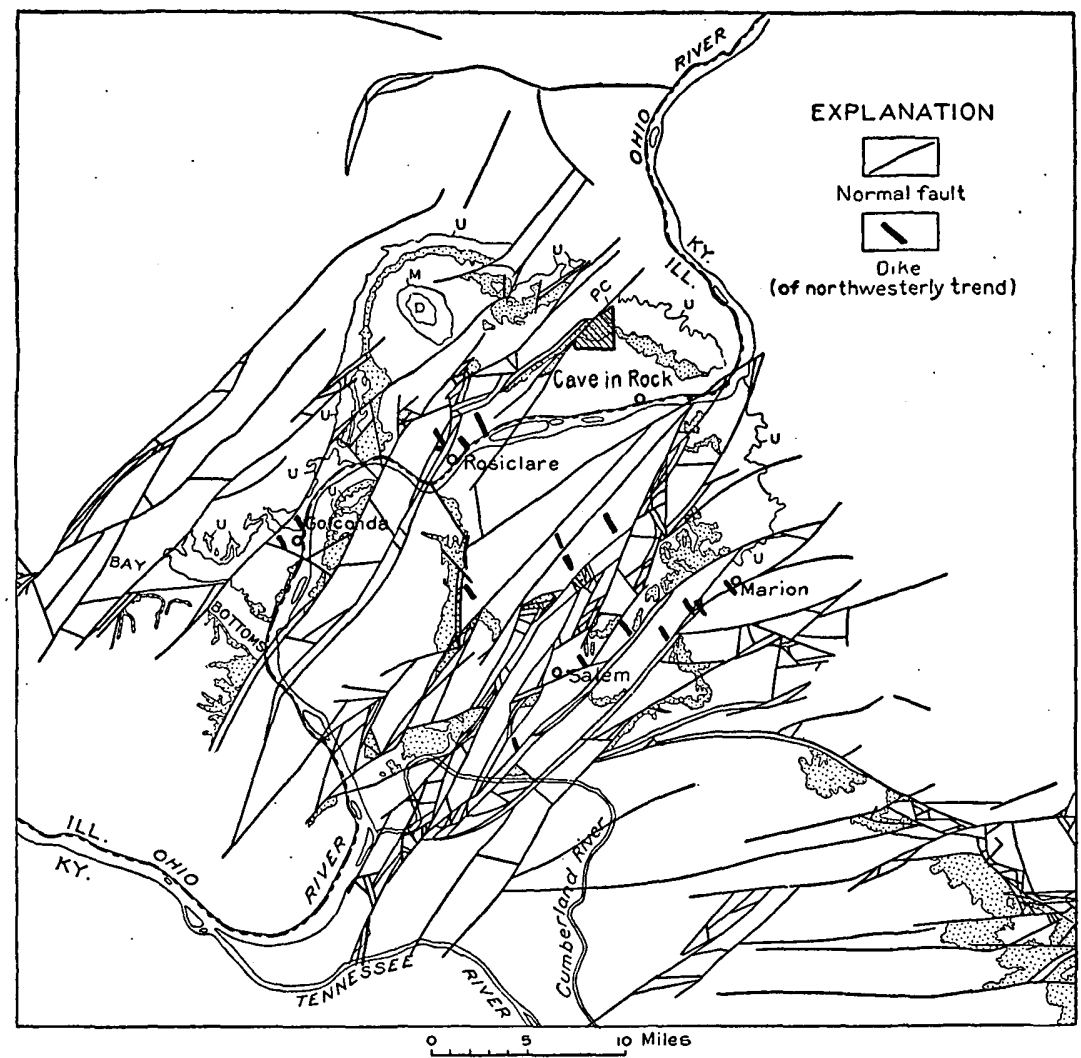

Figure 2.- Map of Illinois-Kentucky fluorspar field. Shaded area, Cave in Rock district, recently mapped in detail. PC, Feters Creek major fault zone. D, Devonian beds (oldest beds of the area). M, outcrop of base of Meramec group. Stippling, area of outcrop of lower formations of Chester gloup. U, outerop of base of upper formations of Chester group. Condensed and abridged from a compiled map furnished through courtesy of J. Marvin Weller.

conclusion that the deposits were directly connected in origin with the molten material intruded beneath the domed area. The distribution of the veins and dikes throughout this area demark it from the surrounding territory as a mineral province in which fluorine-bearing solutions ascended along fault fissures from the deep-seated sources. The geographic center of the disturbed area is apparently in Kentucky, a short distance southeast of Rosiclare.

\section{VEIN DEPOSITS}

Fluorspar and calcite are the chief vein minerals, and they occur in different proportions in different parts of the same vein. In many places calcite is predominant, and at some points on produc- 
tive veins it is the only mineral present. At other places, on the other hand, it is entirely absent. Progressive or consistent changes in proportions of the two minerals with increasing depth have not been established for the field as a whole. It is true that at one mine in the Rosiclare district the vein appeared to change to a calcite vein at certain points below a depth of about 500 feet (AnnexExtension shafts), but there is sound reason to believe that this mine may be on a subordinate, divergent fissure. Elsewhere in the Rosiclare district the productive fluorspar vein has been followed below a depth of 700 feet. Until now most of the deep mining has been confined to the Illinois portion of the field, but it cannot logically be inferred, on the basis of known geologic facts, that the Kentucky veins are limited to shallower depths than those in Illinois. At one mine development has already exceeded a depth of 400 feet. Also, on a theoretical basis, it is reasonable to expect that a generally decreasing concentration of fluorspar will be found toward the marginal belt of the field and that in this belt highgrade concentrations will be comparatively few and scattered.

The major fault fissures are commonly continuous for many miles, and some may extend beyond the mineralized area. Moreover, although the fault fissures may have considerable length, fluorspar masses may be markedly localized within them. Many of the fluorspar deposits have the form of lenticular bodies of commercial grade connected by lean or barren stretches. This is due to the mode of origin and character of the faults. A fault surface rarely approaches a plane configuration, and the differential movement of the undulatory walls results in variable widths and spacings of the open portions of the fissure. As this feature is characteristic in vertical directions as well as horizontal, though perhaps to a lesser degree, the reaching of a "pinch" of the vein at depth does not in itself constitute an argument against sinking to greater depths.

Another structural feature of the veins that is not to be overlooked is that parallel fractures in any one system may converge and unite into a single fissure at depth. This condition is apparent at several places. It is clear, therefore, that a single depth factor, were it known, could not be applied to all the faults as exposed on the surface. It is altogether probable that there are certain very deep-seated fissures that were the controlling channels of access for solutions from the source of supply, and that solutions rising along these master channels were partly deflected into the diverging subordinate breaks, laterally as well as upward. Where the progress of solutions was lateral from the main fissure along a minor intersecting fissure, fluorspar concentration in the minor fissure might be expected to decrease gradually away from the intersection. This consideration, together with the convergence of fissures at depth and 
possible progressive decrease in mineralization in the marginal areas of the field, clearly indicates that no matter what depth factor is assumed, or what ratio of concentration is calculated from existing development work on the veins, the total measured length of faults in the district is not a satisfactory measure of the extent of mineralized territory. It is worth while to recall at this point the wellknown fact that the amount of displacement in a fault is not a measure of the probability or degree of mineralization. In the first place, deeply extending fissures do not necessarily have a great displacement. Again, some faults, especially those of relatively great displacement, may have been so well sealed with gouge at some levels that solutions could not readily ascend along them at and above these levels, whereas some of their auxiliary fissures diverging at a lower horizon may have remained sufficiently open to receive concentrations of potential value.

There are doubtless many small veins that are undiscovered because of thick overburden, and many local rich deposits may be hidden within them. So far there is no known method of locating all or perhaps many of them. Geophysical methods may be very helpful in locating some of the faults, but geophysical data must be cautiously interpreted with respect to known geologic characteristics of the area. Recently resistivity methods have been successfully employed. Where positive results have been obtained, however, faults and not mineral bodies have been indicated, and the task of exploration remains before these faults can be considered potentially productive.

Other minerals commonly present in the fluorspar veins are galena, sphalerite, and quartz. Galena and sphalerite are valuable byproducts at some places and to the extent of their economic recovery play some part in the exploitation of a vein. Quartz is almost universally present, but in many veins it is present in inconsequential amounts. In some places, however, it is so abundant as to preclude treatment of the fluorspar by the usual milling practices, but considerable progress in milling methods has been made in recent years, and some highly siliceous fluorspar may be commercially workable in the future by the use of certain flotation methods. ${ }^{2}$ Although experimentation has been carried on primarily for the purpose of determining methods for producing fluorspar of acid grade (97 percent $\mathrm{CaF}_{2}$ and less than 2 percent $\mathrm{SiO}_{2}$ ) from ordinary fluorspar and for the treatment of mill tailings, it has also been discovered that some highly siliceous fluorspar can be converted to a commercial product. Beneficiation of this sort should have a marked effect

${ }^{2}$ Coghill, W. H., and Greeman, O. W., Flotation of fluorspar ores for acld apar: U. S. Bur. Mines Rept. Inv. 2877, June 1928. Davis, H. W., Fluorspar in 1930: U. S. Bur. Mines Mineral Resources U. S., 1930, pt. 2, pp. 25-26, 1931. 
upon fluorspar reserves as deposits of low-silica ores approach depletion.

The foregoing discussion points out the different geologic factors and uncertainties involved in attempts to estimate reserves of vein fluorspar in the Illinois-Kentucky field. In 1927 a joint committee of the American Institute of Mining and Metallurgical Engineers and the Mining and Metallurgical Society of America prepared an estimate of fluorspar reserves in this field. So far as the calculation applies to the vein deposits the estimate of approximately 5,000,000 tons of milled fluorspar (at 70 percent recovery) seems reasonably conservative and cannot be definitely modified by quantitative data now at hand. Considering the geologic factors, however, the committee's estimate for the marginal belt of the field probably errs in being too high, whereas the estimate for the central area-particularly for the Kentucky portion-is probably too low. As suggested by the geologic facts stated above, the combined length of known faults, and limiting depths based on mine development to date seem to be unsatisfactory bases for calculation. On the whole, however, it is the writer's opinion that the committee's total figure represents a rational and conservative estimate of the future expectancy in vein fluorspar as a national resource. Realization will, of course, be conditioned by the degree of thoughtfully planned and executed exploration and development, in which geologic interpretation and geophysical methods will play important parts.

\section{BEDDING REPLACEMENT DEPOSITS}

The fluorspar deposits in the Cave in Rock district are clearly replacement bodies in certain beds near the top of the thick Ste. Genevieve limestone. The limestone beds and hence the more or less tabular fluorspar bodies are essentially in a horizontal position, and the depth at which they occur can be rather closely determined from a knowledge of the areal geology. In the greater part of the developed area the chief ore zone is exposed along slopes and is easily opened through adits. Elsewhere exploration is satisfactorily accomplished by drilling. However, only a small amount of exploration has been done in advance of development, and the computation of reserves must be based largely on geologic data gained at the surface and interpreted through knowledge of the structural features, richness, and relationships of the known fluorspar bodies.

Certain stratigraphic and structural conditions appear to have controlled the deposition of fluorspar as bedding replacement bodies in this district. The most favorable horizon, so far as is indicated by development, is that part of the Ste. Genevieve limestone that directly underlies the Rosiclare sandstone member of the formation. The warped shale base of this sandstone forms the roof of fluorspar 
bodies at this horizon. This shale is only a few inches to a few feet thick but appears to have formed an effective barrier to fluorinebearing solutions that rose along local or minor fissures. The fissures have little or no displacement. It is believed that they were favorable channels of access wherever they extended upward only to the impervious beds or were greatly reduced in passing from the limestone into the shale caprock. This termination or restriction may well have caused a "damming" effect upon solutions rising along the fissures and have forced them to penetrate laterally into the permeable and chemically susceptible limestone beds. As a result the beds were replaced more or less completely for considerable distances. It is conceived that these minor fissues were connected lower down with other channels and ultimately with a major fault zone. On this theory, extensive bedding replacement deposits are to be sought only in areas where a broad zone of minor fissuring and faulting lies adjacent to a major fault zone. It is unlikely that they would be commonly found in the walls of major fault zones, where ascension of solutions was relatively unhampered. The presence of a dense, impermeable bed, such as the shale base of the Rosiclare sandstone, or, subordinately, of dense limestone beds, is also a requirement. It is also reasonable to assume that such deposits will tend to be limited to marginal areas of the field.

A geologic estimate of reserves in the Cave in Rock district can be approached somewhat more satisfactorily than one of the vein deposits, not because the geologic features are more apparent, but because they can be evaluated better. As shown by the foregoing discussion, the geologic relations of the deposits permit elimination of the troublesome depth factor, and, if the theory of origin is correct, the probable areal distribution can be more satisfactorily prophesied on the basis of areal geology; moreover, the present mining developments furnish reasonable data for computing a concentration factor. Still, as is always true of the geologic approach to such a problem, certain assumptions must be made regarding the probable percentage of mineralized ground.

The factors involved in the calculation of reserves in the Cave in Rock district are (1) area of geologically favorable territory, (2) proportion of this area that is mineralized, (3) average thickness of mineral bodies, (4) percentage recovery of marketable fluorspar per unit of mined material.

Mapping and studies recently carried on in the district ${ }^{3}$ indicate an area of about $11 / 2$ square miles in which favorable geologic conditions may be present. Of this area about 150 acres is developed and explored, 150 acres constitutes "probable" ground as indicated

\footnotetext{
- Report in preparation on a cooperative project between the United States Geological Survey and the Illinois State Geological Survey, started in 1934 under auspices of the Public Works Administration, continued in 1935 by the two Surveys.
} 
by prospects and drill records, and the remaining 600 to 700 acres constitutes "possible" ground in which the known major geologic. features are favorable.

On the basis of data obtained in the mines of the district and of certain mining and milling data provided by the several companies, the following factors have been derived for use in computing the reserves:

1. The average thickness of ore bodies in the mined territory is from 3 to $3 \frac{1}{2}$ feet. This is actually an average measure of the chief mineralized zone in all the mines that were accessible at the time of the investigation.

2. The average fluorspar content of mined material is considered to be about 70 percent.

3 . The average recovery of merchantable fluorspar from crude "ore" is believed to be about 75 percent.

4. About 30 percent of the "probable" and developed areas is. assumed to be mineralized.

5. The porosity of crude fluorspar as mined is liberally estimated at 10 percent.

By considering the weight of a cubic foot of pure fluorspar to be 200 pounds, and applying all these factors to the 300 acres of developed and "probable" ground, the calculation gives. a probable supply of 556,000 tons. About 150,000 tons has already been marketed from the district. This leaves an estimate in "probable" ground of approximately 400,000 tons. If between 5 and 10 percent of the "possible" area is arbitrarily assumed to be mineralized, and the other concentration factors remain the same, it should contain a possible reserve of approximately 300,000 tons. The total calculated reserve would accordingly be about 700,000 tons. This estimate does not allow for fluorspar at lower horizons of the limestone which, according to recent explorations, may be appreciably productive. According to geologic inferences and the concentration data given above, therefore, we may conservatively expect a total future production of 500,000 to 700,000 tons of marketable fluorspar (fluxing grade) from the district. In no sense, however, should any considerable part of this estimated total be looked upon as "blocked out." It should be clearly understood that the estimate rests largely upon. geologic interpretation and of necessity could not be based mostly on data obtained in mining exploration. It will probably be most useful in stimulating legitimate interest in certain undeveloped portions of the district and in supporting a reasonable opinion as. regards the potential resources of this materially important mineral.

It is interesting to note that the committee referred to above estimated the reserves of the Cave in Rock district to be only 80,000 tons. Since that estimate was made, notable developments have disclosed large fluorspar bodies and have extended the proved territory; also. 
since that time the district has marketed approximately 100,000 tons of fluorspar.

\section{LIFE OF THE ILLINOIS-KENTUCKY FIELD}

The present factors of utilization of fluorspar in the basic openhearth steel and other industries suggest that the average consumption of fluorspar in the United States for prosperous years comparable with 1928-29 will be between 150,000 and 200,000 tons. The import rate is now about 15,000 tons a year-an amount that is negligible in the present calculation. At an assumed average yearly consumption of 175,000 tons, therefore, the estimated reserves of $5,500,000$ or $6,000,000$ tons will last 30 to 35 years. ${ }^{4}$

Several indeterminate economic factors will doubtless affect the production and reserves. In recent years there has been some increase in the use of fluorspar in industries other than steel making, but so far this diversion has not had any marked effect, as is apparent from the curve in plate 1 showing the percentage of domestic fluorspar used in the steel industry. What the next few years will bring about in this direction depends, of course, not only upon general industrial progress but also upon chemical advances. It is highly improbable, however, that the steel industry will lose its domination of the fluorspar industry, and consequently the fluorspar operators will continue to find their chief markets in the steel-manufacturing districts.

There are many deposits of fluorspar of too low grade for present mining that should ultimately contribute to the resources through advances in milling methods. Lower-grade deposits will inevitably be of increasing importance with the gradual depletion of the highergrade deposits. Narrower veins will be worked and greater depths reached. Additional costs of mining and milling must necessarily bring higher prices for the product. A considerable increase in the market price of fluxing fluorspar, however, should not be felt appreciably by the steel industry, because, according to the average utilization factor in 1935 of $61 / 2$ pounds of fluorspar per ton of steel, the cost of the flux in 1935 was less than $4 \frac{1}{2}$ cents per ton of finished steel.

Finally, although the present import level is low, there have been periods in recent years when domestic production has been greatly affected by large imports. (See pl. 1.) The future volume of imports and their consequent effect upon depletion of reserves cannot be prophesied.

- Statistics for production, imports, and utilization factors were obtained from data in Mineral Resources of the United States, published by the U. S. Geological Survey from 1916 to 1923 and by the U. S. Bureau of Mines from 1924 to 1932 ; and in the Minerals Yearbook, published by the U. S. Bureau of Mines in 1933, 1934, and 1935; also from records of the U. S. Bureau of Mines, through the courtesy of the Director of that Bureau. 

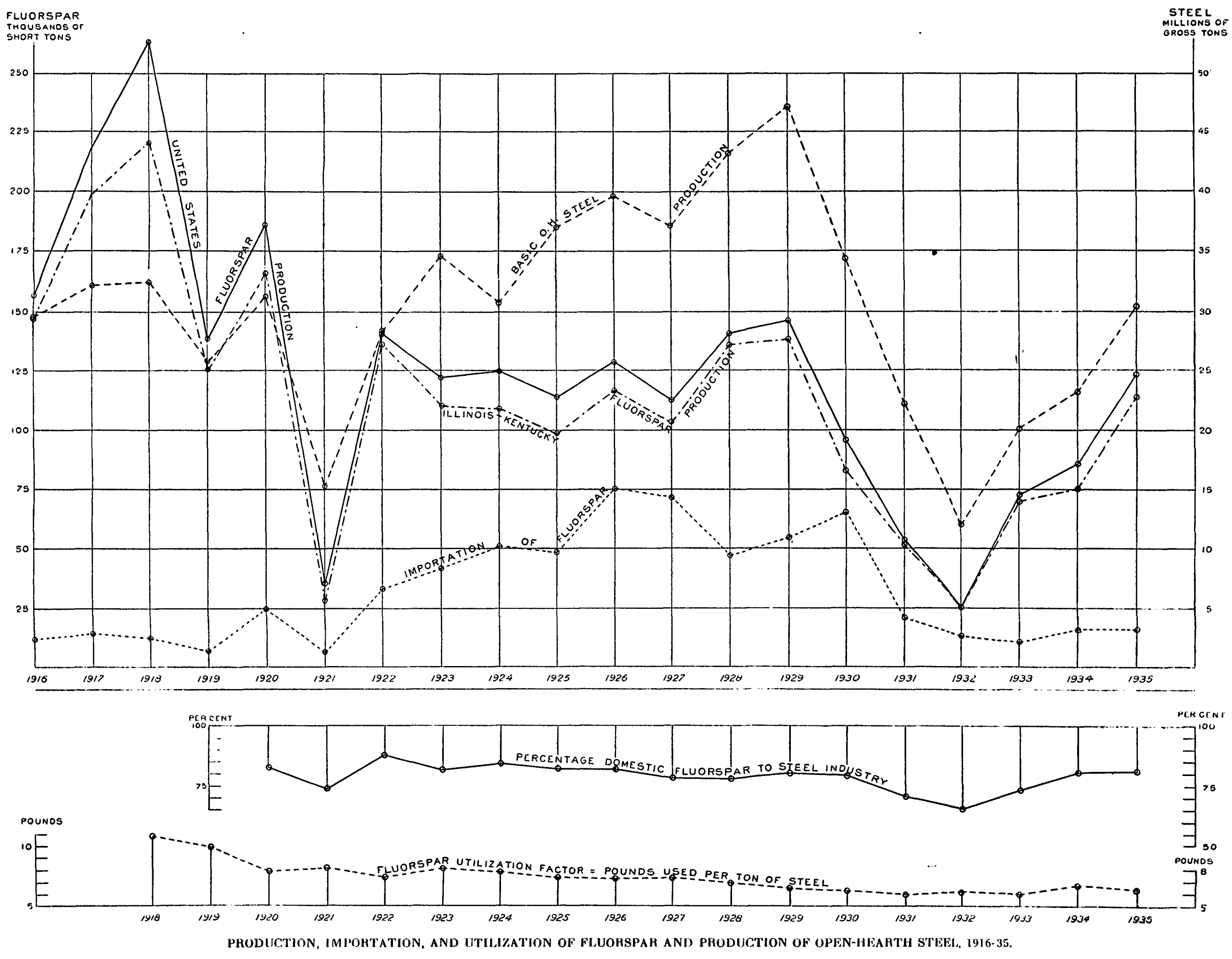